\title{
AN ANALYSIS OF FOODSERVICE AND ACCOMMODATION INDUSTRY IN EUROPE USING SECONDARY STATISTICS
}

\author{
Edyta Gheribi $i^{\mathrm{a}}$,Alessandro Bonadonna ${ }^{\mathrm{b}}$ \\ a'University of Lodz, Department of Finance and Strategic Management, \\ Lodz, Poland \\ ${ }^{b}$ University of Turin, Department of Management, Turin, Italy \\ ae-mail: edyta_kwiatkowska@interia.eu \\ be-mail: alessandro.bonadonna@unito.it
}

\begin{abstract}
The foodservice and accommodation industry makes a major contribution to the European economy. This industry has been particularly chosen for a study because it is an important and extremely competitive and dynamic industry, which is characterized by continuous transformation. The article presents an overview and analysis of the foodservice and accommodation industry in countries in the European Union (EU) to assess its importance in the European economic system. Secondary sources of information were used to reach the scope of the paper. The analysis presented in this article is based on the main dataset for structural business statistics (SBS), size class data and regional data. The research period was the years 2010-2014. A comparative method was applied for the analysis of collected data and materials. In this research, industrial analysis was used, which was a statistical analysis of the size, demographic, and other economic dimensions of any industry of an economy. Findings show that this industry contributes to job creation and economic growth in favorable times but the support of decision-makers, legal and fiscal rules is needed if the hospitality industry must be considered for a key driver for welfare and sustainability in Europe.
\end{abstract}

Keywords: foodservice, accommodation, hospitality, European Union

Paper type: Research paper

\section{Introduction}

Travel and tourism is an important economic activity in most countries around the world. As well as its direct economic impact, the industry has significant indirect and induced impacts (WTTC, 2017). The hospitality industry is a sub-part of travel and tourism and is growing very rapidly (International Labor Organization, 2010 ) with a contribution nearly to 10\% of the world's GDP (Boella, 2000). The European tourism industry generates over 5\% of EU's GDP, a figure which is steadily rising (European Commission, 2010). The hospitality industry includes 
AN ANALYSIS OF FOODSERVICE AND ACCOMMODATION

Edyta Gheribi

Alessandro Bonadonna enterprises that provide accommodation, meals and drinks in venues outside the home. The tourism industry that included the hospitality sub-part represents the third largest socioeconomic activity in the EU after the trade and distribution and construction industry. In the European Union, foodservice accounts for the largest sub-part of the hospitality industry. Foodservice business and accommodation are one of the most vigorous industries of the European economy. In today's world, service of these businesses plays an important role in successfully meeting the changing needs of consumers. The foodservice sub-part generates the largest part of value-adding and the majority of jobs in the hospitality industry. Social and demographic trends, as well as changing values in society, and consumer perceptions promote the development of new opportunities and products in the hotel, foodservice and tourism industry (Atkins and Bowler, 2001; GDFHTS, 2010; Gheribi, 2015a; Gheribi and Voytovych, 2018). Stable economic conditions, labor market development, and accelerating the pace of life will further boost this sector (Robinson et al., 2013; Gheribi, 2017).

The foodservice business is an important part of tourism economy. In recent decades tourism has become one of the most important service industries in the global economy. The development of foodservice services and tourism are closely linked. Between foodservice and tourism there is a feedback loop (Gheribi, 2015b)). The modern tourist has been involved in a cultural, ethical and economic change and the re-discovery of taste is a part of it. Indeed, this change has led to the safeguarding of territorial typicality (Barjolle and Sylvander, 2000; Peri, 2006; Ikerd, 2011), protection of the territorial local identity (Tregear et al., 1998; Belliveau, 2005; Morgan et al., 2006; Vanhonacker et al., 2010) and the creation of economic business known as "Economy of Taste" (Peira et al., 2018). Moreover, local and regional food could give added-value to the destination and contribute to the competitiveness of the area. The territory is the backbone of foodservice offerings. The territory is an element that differentiates and is the source of local identity. It encompasses environmental and landscape values, history, culture, tradition, the countryside, the sea, the own cuisine of the place. In this regard, the conversion of the territory into a culinary landscape is one of the challenges of tourism destinations. Foodservice allows tourists to access the cultural and historical heritage of destinations through tasting, experiencing and purchasing. On the other hand, eating out has become a recreation, food is not only for satisfying the hunger, but is also a kind of entertainment. Figure 1, below, illustrated the overlap and inter-related nature of the relationship between the tourism and hospitality industries.

The EU-28's tourist arrivals increased between 2004 and 2014 by almost $80 \%$ (UNWTO, 2015).

There were around 1.133 million international tourist arrivals worldwide in 2014, among which 455 million (40.2\%) were recorded in the EU-28 (UNWTO, 


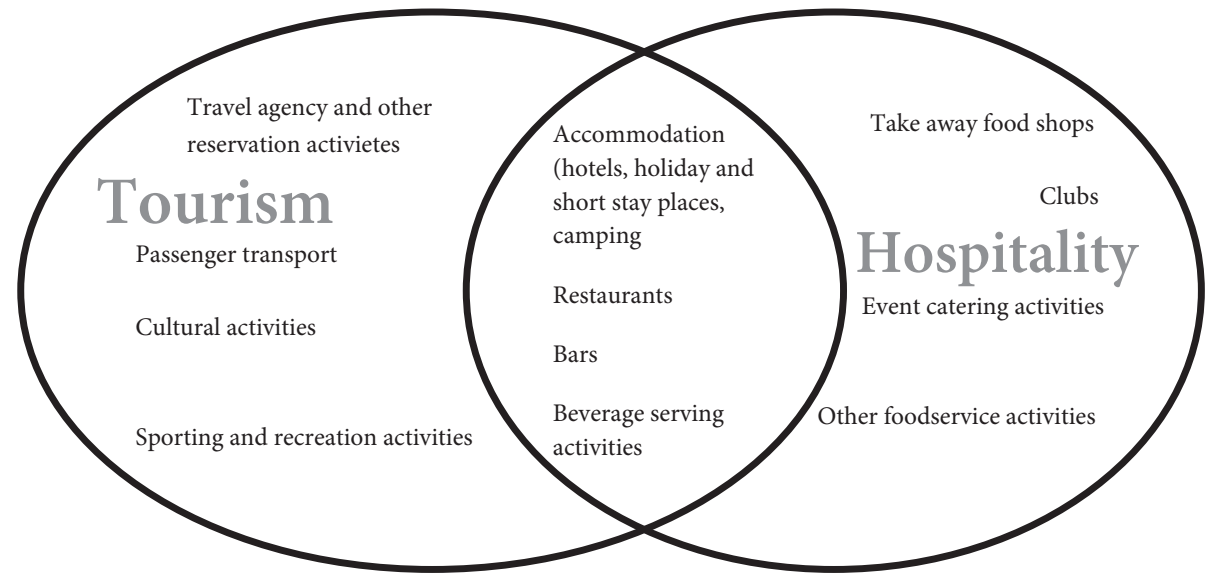

AN ANALYSIS OF FOODSERVICE AND ACCOMMODATION

Edyta Gheribi

Alessandro Bonadonna

Figure 1. Mapping of tourism and hospitality industries Source: own model.

2015). The EU-28 therefore was the world's major tourist destination although it should be noted that the EU total includes arrivals in EU Member States of tourists from other EU Member States. More than three out of four enterprises in the tourism industries operated in accommodation (NACE I55) or food and beverage serving activities (NACE I56) accounting for $12 \%$ and $65 \%$ respectively (Eurostat, 2017).

The food service and accommodation industry is not only an important economic, but also a major social and cultural contributor. Hospitality is at the heart of European society, where bars, cafés and restaurants are places to meet, have fun and get inspired. For locals and tourists alike, the food service and accommodation industry enhances our enjoyment of life. Activities of food service and accommodation make up a significant part of tourism supply, although they also serve local clients and business customers.

Eating out has become a common everyday practice for many consumers, and with an added value of 230,5 million EUR, the market has become an important part of the food industry (Eurostat, 2017). Studies suggest that in Europe one in four meals is consumed outside the home, one in every two meals is taken at the workplace, and more than one in four meals is taken at school (Ferco, 2015).

On the basis of aforementioned information, this study attempts to know the real importance of foodservice and accommodation industry in the European Union and related outcomes for economic growth and job creation.

This paper is organised in following three sections over the present introduction. The first section provides information on materials and methods used to collect and analyse data; the second section highlights findings and the main results achieved on the basis of the collected data; the third and final section conclusions, together with implications, limitations of the study and future research directions. 
AN ANALYSIS OF FOODSERVICE AND ACCOMMODATION

Edyta Gheribi

Alessandro Bonadonna

\section{Materials and methods}

In order to collect the necessary data and information, statistical analysis approach was used to reveal the main developments in foodservice and accommodation industries in European Union. The scenarios of the 2010-2014 period were examined using the available secondary sources such as data from European Statistics (Eurostat), business reports, industry newsletters and publications, in line with other authors (Sheresheva et al., 2018; Sobaih, 2015; Coroş and Negrușa, 2014). Indeed, the analysis presented in this article is based on the main dataset for structural business statistics (SBS), size class data and regional data, all of which are published annually, in line with other authors (Slattery et al., 2008). A comparative method was applied for the analysis of collected data and an industrial analysis was used, which is a statistical analysis of the size, demographic, and other economic dimensions of any industry of an economy.

\section{Foodservice and accommodation sector - sectoral analysis}

The analysis refers to four selected indicators: the number of enterprises, the number of persons employed, the turnover and the value-added at factor cost firstly at EU, secondly at country level.

In 2014, in EU-28 the accommodation and food services industry recorded added value of EUR 230,5 million and employed 10.8 million persons, many of them on a part-time basis (Eurostat, 2017). Its workforce is also characterized by a large number of working proprietors and unpaid family workers because a lot of these enterprises are family enterprises.

The food service and accommodation industry is a labor-intensive one, dominated by small businesses and characterized by low levels of affiliation to employer organizations and trade unions.

The number of enterprises in 2014 reflected the small average size of the 1,87 million enterprises in the EU-28's accommodation and food services industry, but was higher by $4.7 \%$ compared to 1,78 in 2010 in EU-27.

In 2014, the number of persons employed was 10,8 million and was higher by $6.9 \%$ compared to 10,1 million in 2010 in EU-27. The industry supports a flexible labor market, providing work for young and first time labor market entrants and those returning to the job market (Gheribi and Ejsmont, 2018). With youth unemployment now firmly on the agendas of Europe's political leaders, the potential for the food service and accommodation industry to continue to provide jobs should not be overlooked. This industry is one of the most important gateways to the labor market, which is crucial in the current times of high unemployment, especially amongst young people in Europe. Frequent claims are made for the importance of the hospitality industry, and wider tourism one, as potential and actual creators of employment. Many of these claims emanate from industry representative and advocacy organizations, often as part of their legitimate efforts 
to lobby governments for favorable treatment of their industries (Koens and Wood, 2017).

Working conditions in the industry can be very different from those in other service industries. Consumer demand patterns in hotels and restaurants require working conditions that are frequently characterized as unsocial and irregular working hours in the form of split shifts, weekend shifts, nightshifts, or work during holiday periods (Busquets, 2010).

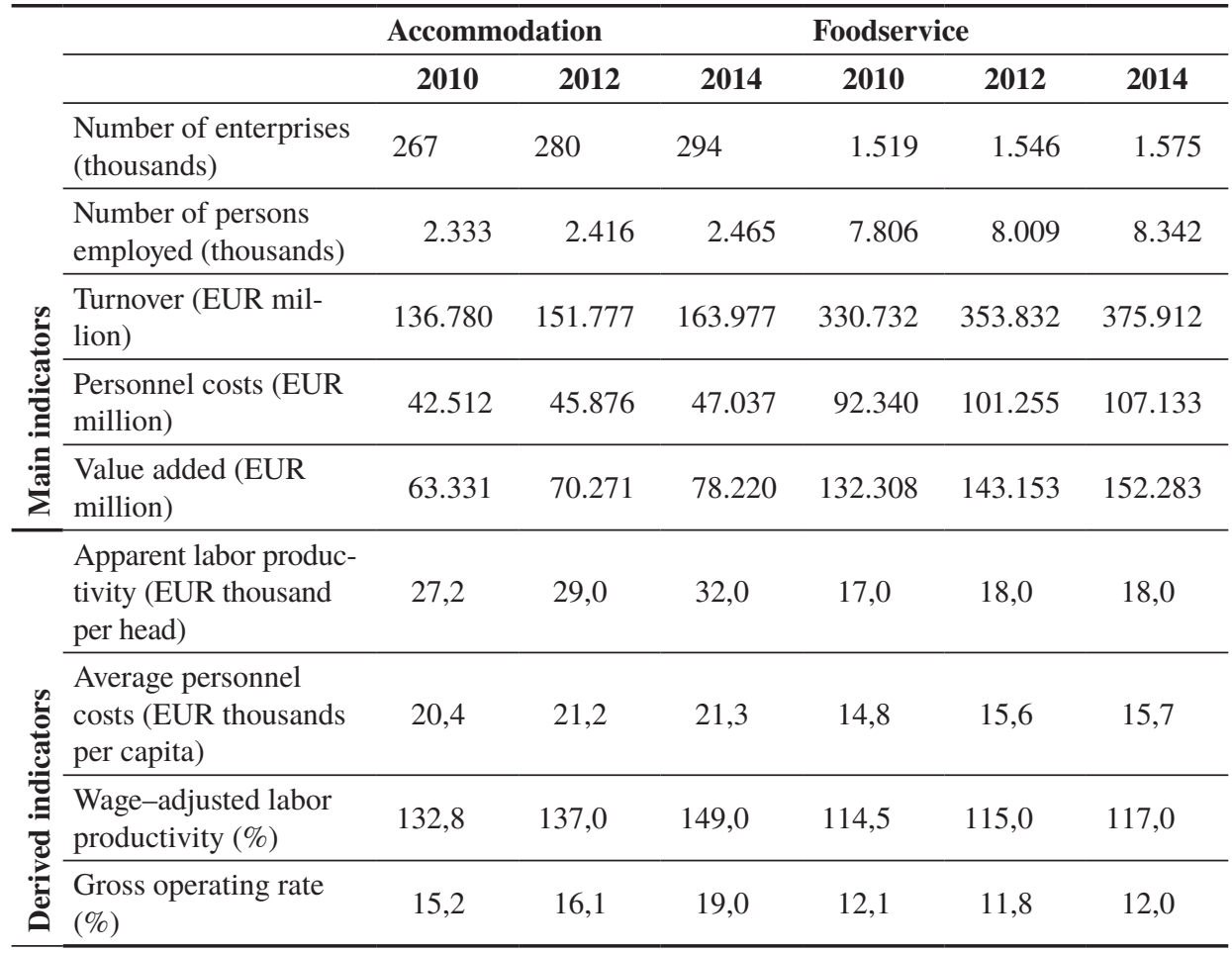

In 2014, apparent labor productivity compared to 2010 and 2012 of EUR 21,0 thousand per person employed for the accommodation and food services industry was recorded on Eurostat data (32,0 thou. in accommodation and 18,0 thou. in food and beverage service activities) alongside average personnel costs of EUR 17,0 thousand per employee (21,3 thou. in accommodation and 15,7 thou. in food and beverage service activities) (shown in Table 1). However, both of these indicators are pulled downwards by the traditionally high incidence of parttime employment in the accommodation and food services industry. The wageadjusted labor productivity ratio is not directly affected by part-time employment as it shows the ratio between values added and total personnel costs without
AN ANALYSIS OF FOODSERVICE AND ACCOMMODATION

Edyta Gheribi Alessandro Bonadonna

Table 1. Food service and accommodation sector in Europe in 2010-2014

Source: own calculation based on Eurostat, 2017. 
AN ANALYSIS OF FOODSERVICE AND ACCOMMODATION

Edyta Gheribi

Alessandro Bonadonna relating this to the number of persons producing the output or receiving wages and salaries. Hotels and restaurants are major employers of young people and there are more women than men working in this industry. Large numbers of seasonal workers are hired in addition to permanent staff during peak periods.

The combination of low productivity and personnel costs in the EU-28's accommodation and food services industry led to a wage-adjusted labor productivity ratio of $125.0 \%$ in 2014 , which was the third lowest value across the NACE sections within the non-financial business economy. By contrast, the gross operating rate which shows the share of turnover that remains after paying for purchased goods and services and personnel costs (in other words, the gross operating surplus) was $14.1 \%$ for the EU-28's accommodation and food services industry in 2014; which was more than one third higher than the non-financial business economy average $(10.1 \%)$ (Eurostat, 2017). The gross operating rate is one measure of operating profitability and it stood at $16.1 \%$ for the EU-28's accommodation services industry in 2012, and $19 \%$ in 2014, around 1,7 times as high as the non-financial business economy average of $9.4 \%$. The gross operating rate for the EU-28's food and beverage services industry in 2014 was 12,0 and in 2012 was $11.8 \%$. The low apparent labor productivity figure for the EU-28's accommodation and food services industry in 2014 was pulled downwards by the food and beverages sub-industry, where an average of EUR 18,0 thousand of value was added per person employed, compared with EUR 32,0 thousand within the accommodation sub-industry. As such, the food and beverages sub-industry had the lowest apparent labor productivity ratio in 2014 among all NACE division.

Equally, average personnel costs in 2014 were lower for the food and beverages subs-industry (EUR 15,7 thousand) than for the accommodation sub-industry (EUR 21,3 thousand). The EU-28's food and beverages sub-industry recorded the lowest level of average personnel costs among the non-financial business economy NACE divisions in 2014. As already noted, many activities in the accommodation and food services industry have a high incidence of part-time employment and wage-adjusted labor productivity is an indicator that is less influenced by this characteristic.

In 2014, the accommodation sub-industry recorded a wage-adjusted labor productivity ratio of $149.0 \%$, while the food and beverages sub-industry recorded a ratio of $117.0 \%$. For the gross operating rate, the above average value for the whole of the EU-28's accommodation and foodservice industry (14.1\% in 2014) was pulled up by the $19.0 \%$ rate recorded for the accommodation sub-industry, although the gross operating rate for the food and beverages sub-industry $(12.0 \%)$ was also above the non-financial business economy average $(10.1 \%)$.

According to most structural business indicators, the food and beverages subindustry (Division 56) is larger than the accommodation sub-industry (Division 55). The food and beverages sub-industry accounted for $84.2 \%$ of all enterprises 
in the EU-28's accommodation and food services industry in $2014,77.2 \%$ of the persons employed and $66.1 \%$ of industrial value added.

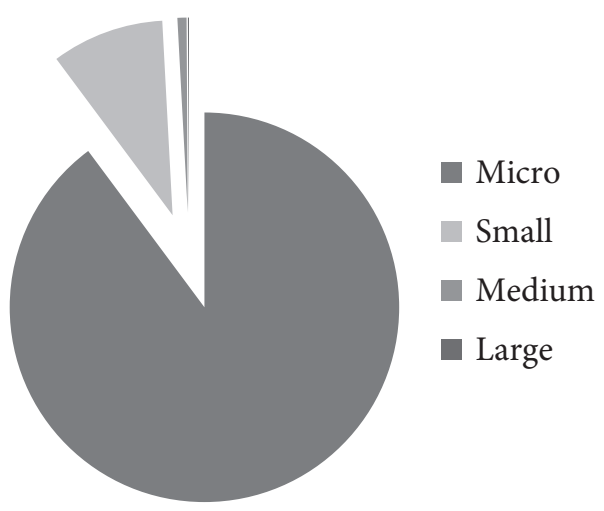

The enterprise size structure of the EU-28's accommodation and food services industry appeared to be dominated by micro enterprises (employing fewer than 10 persons). These enterprises employed $41.1 \%$ of the EU-28's accommodation and food services workforce in 2014 and generated $30.8 \%$ of its value added. Small enterprises (employing 10 to 49 persons) also accounted for a higher than average share of the workforce and added value, in both cases around a third of the total. The relative importance of medium-sized enterprises (employing 50 to 249 persons) and particularly large enterprises (employing 250 or more persons) was low in the accommodation and food industry, combining for just $17.3 \%$ of the EU-28's total workforce and $24.7 \%$ of its value added (Table 2).

\begin{tabular}{llll}
\hline & $\begin{array}{l}\text { Number of persons } \\
\text { employed } \\
\text { (thousands) }\end{array}$ & $\begin{array}{l}\text { Value added } \\
\text { (EUR million) }\end{array}$ & $\begin{array}{l}\text { Apparent labor produc- } \\
\text { tivity (EUR thousand per } \\
\text { capita) }\end{array}$ \\
\hline All enterprises & $10.807,9$ & $230.504,0$ & 21,3 \\
\hline All SMEs & $8.946,3$ & $137.541,2$ & 15,4 \\
\hline Micro & $4.446,3$ & $71.108,4$ & 16,0 \\
\hline Small & $3.200,0$ & $66.432,8$ & 20,8 \\
\hline Medium-sized & $1.300,0$ & Not available & Not available \\
\hline Large & $1.866,1$ & $56.966,9$ & 30,5 \\
\hline
\end{tabular}

The share of micro enterprises was particularly high for the EU-28's food and beverage services sub-industry, generating $36.6 \%$ of the added value and employing $46.3 \%$ of the total workforce in this sub-industry in 2014. Medium-
AN ANALYSIS OF FOODSERVICE AND ACCOMMODATION

Edyta Gheribi Alessandro Bonadonna

Figure 2. The enterprise size structure of the EU28's accommodation and food services sector in $2014(\%$ share of sectoral total).

Source: own calculation based on Eurostat, 2017.

Table 2. Size class indicators in accommodation and foodservice activities in EU-28 in 2014

Source: own calculation based on Eurostat, 2017. 
AN ANALYSIS OF FOODSERVICE AND ACCOMMODATION

Edyta Gheribi Alessandro Bonadonna

Table 3.

Employment by enterprise size class, accommodation and food service activities in 2010 2014

Source: own calculation based on Eurostat, 2017, 2014, 2010.

Table 4. Value added by enterprise size class, accommodation and food service activities in 20102014

Source: own calculation based on Eurostat, 2017, 2014, 2010. sized enterprises in the accommodation sub-industry were important with a $24.3 \%$ share of added value and a $26.9 \%$ share of the workforce; while small enterprises employment share (13.4\%) generated a slight larger share of the workforce $(29.9 \%)$.

The food and beverage services industry reported a relatively important role for micro enterprises (employing fewer than 10 persons). There were 1,4 million micro enterprises active within the EU-28's food and beverage services industry in 2012. Together they generated EUR 59,3 billion of added value and employed 3,8 million persons. As such, they accounted for a $41.4 \%$ share of value added within the EU-28's food and beverage services industry and a $47.4 \%$ share of employment.

\begin{tabular}{lcrrrc}
\hline Specification & Accommodation & Foodservice & $\begin{array}{c}\text { Accommo- } \\
\text { dation and } \\
\text { foodservice }\end{array}$ \\
\hline Year & $\mathbf{2 0 1 0}$ & $\mathbf{2 0 1 2}$ & $\mathbf{2 0 1 0}$ & $\mathbf{2 0 1 2}$ & $\mathbf{2 0 1 4}$ \\
\hline SMEs (1-249 person employed) & 80,9 & 80,8 & 81,6 & 83,7 & 82,8 \\
\hline Micro (< 10 person employed) & 24,0 & 23,1 & 46,1 & 47,4 & 41,1 \\
\hline Small (10-49 person employed) & 32,4 & 32,9 & 26,9 & 27,6 & 29,6 \\
\hline Medium (50-249 person employed) & 24,5 & 24,8 & 8,7 & 8,8 & 12,0 \\
\hline Large (> 250 person employed) & 19,1 & 19,3 & 18,4 & 16,4 & 17,3 \\
\hline
\end{tabular}

The accommodation services sector also reported a relatively important role for small enterprises (employing 10 to 49 persons). There were 39,7 thousand small enterprises active within the EU-28's accommodation services sector in 2012. The accommodation and foodservice sector generated EUR 21,6 billion of added value and employed 794 thousand persons. As such, they accounted for a $30.8 \%$ share of value added within the EU-28's accommodation services sector and a $32.9 \%$ share of employment.

\begin{tabular}{lccccc}
\hline Specification & Accommodation & \multicolumn{2}{l}{$\begin{array}{l}\text { Foodservice } \\
\text { sector }\end{array}$} & $\begin{array}{l}\text { Accommodation and } \\
\text { foodservice sector }\end{array}$ \\
\hline Year & $\mathbf{2 0 1 0}$ & $\mathbf{2 0 1 2}$ & $\mathbf{2 0 1 0}$ & $\mathbf{2 0 1 2}$ & $\mathbf{2 0 1 4}$ \\
\hline SMEs (1-249 person employed) & 77,0 & Not available & 77,5 & 76,4 & 59,7 \\
\hline Micro (<10 person employed) & 20,9 & Not available & 43,7 & 41,4 & 30,8 \\
\hline Small (10-49 person employed) & 31,9 & 30,8 & 25,1 & 25,7 & 28,8 \\
\hline $\begin{array}{l}\text { Medium (50-249 person em- } \\
\text { ployed) }\end{array}$ & 24,1 & 26,6 & 8,7 & 9,3 & 15,7 \\
\hline Large (> 250 person employed) & 23,0 & Not available & 22,5 & 23,8 & 24,7 \\
\hline
\end{tabular}


Geographic location is one of the most important factors for the foodservice and accommodation industry. Analyzing the foodservice and accommodation industry in each of EU-28 countries, it was observed that five member states had the highest key indicators. It must be noted that the EU-28 member states with the most number of foodservice and accommodation enterprises was: Italy (312 thou.), Spain (269,9 thou.), Germany (226,2 thou.) and the United Kingdom (132,1 thou.). In these countries, the highest number of persons employed in foodservice and accommodation industry were noted as Germany (2.085 thou.), the United Kingdom (2.043,4 thou.), Italy (1.295,9 thou.), Spain (1.210,7 thou.), France (1.027,3 thou.). Data analysis indicates that turnover from foodservice and accommodation was highest in the United Kingdom (101.962,9 million), France (90.200,0 million), Germany (77.404,1 million), Spain (57.875,5 million) and Italy (71.642,1 million). Value added in million EUR was highest in the United Kingdom (50.059,6), France $(36.257,6)$, Germany $(36.062,5)$, Italy $(27.455,0)$ and Spain $(24.493,8)$. Analyzing the personnel costs (EUR million) in EU-28, it was noted that highest cost was in France $(29.587,6)$, the United Kingdom $(28.155,6)$, Germany $(22.652,5)$, Spain $(18.167,7)$ and Italy $(17.682,7)$. Detailed data is presented in the Table 5 .

\begin{tabular}{lrrrrr}
\hline $\begin{array}{l}\text { Specifi- } \\
\text { cation }\end{array}$ & $\begin{array}{l}\text { Number of } \\
\text { enterprises } \\
\text { (thousands) }\end{array}$ & $\begin{array}{l}\text { Number } \\
\text { of persons } \\
\text { employed } \\
\text { (thousands) }\end{array}$ & $\begin{array}{l}\text { Turnover } \\
\text { (EUR million) }\end{array}$ & $\begin{array}{l}\text { Value added } \\
\text { (EUR million) }\end{array}$ & $\begin{array}{l}\text { Personnel } \\
\text { costs (EUR } \\
\text { million) }\end{array}$ \\
\hline EU-28 & $1.869,9$ & $10.807,9$ & $539.889,9$ & $230.504,0$ & $154.170,7$ \\
\hline Belgium & 49,1 & 179,7 & $14.296,9$ & $5.102,3$ & $3.177,0$ \\
\hline Bulgaria & 26,3 & 136,5 & $1.853,4$ & 612,2 & 407,9 \\
\hline Czech & 59,0 & 162,3 & $4.729,9$ & $1.524,4$ & 914,1 \\
Republic & 13,7 & 72,8 & $7.044,0$ & $2.950,3$ & $2.239,6$ \\
\hline Denmark & 226,2 & $2.085,0$ & $77.404,1$ & $36.062,5$ & $22.652,5$ \\
\hline Germany & 2,5 & 22,6 & 735,5 & 259,0 & 201,6 \\
\hline Estonia & 17,8 & 161,1 & $9.750,1$ & $3.925,2$ & $3.147,6$ \\
\hline Ireland & 90,6 & 317,2 & $9.865,6$ & $3.755,6$ & $2.233,1$ \\
\hline Greece & 269,9 & $1.210,7$ & $57.875,5$ & $24.493,8$ & $18.167,7$ \\
\hline Spain & 273,0 & $1.027,3$ & $90.200,0$ & $36.257,6$ & $29.587,6$ \\
\hline France & 19,5 & 97,6 & $3.083,6$ & $1.414,1$ & 806,0 \\
\hline Croatia & 312,0 & $1.295,9$ & $71.642,1$ & $27.455,0$ & $17.682,7$ \\
\hline Italy & 5,3 & 37,9 & $1.883,6$ & 977,4 & 519,9 \\
\hline Cyprus & 3,6 & 32,8 & 665,6 & 231,6 & 167,9 \\
\hline Latvia & & & & & \\
\hline
\end{tabular}

AN ANALYSIS OF FOODSERVICE AND ACCOMMODATION

Edyta Gheribi Alessandro Bonadonna 
AN ANALYSIS OF FOODSERVICE AND ACCOMMODATION

Edyta Gheribi

Alessandro Bonadonna

Table 5.

continued

\begin{tabular}{lccccc}
\hline $\begin{array}{l}\text { Specifi- } \\
\text { cation }\end{array}$ & $\begin{array}{l}\text { Number of } \\
\text { enterprises } \\
\text { (thousands) }\end{array}$ & $\begin{array}{l}\text { Number } \\
\text { of persons } \\
\text { employed } \\
\text { (thousands) }\end{array}$ & $\begin{array}{l}\text { Turnover } \\
\text { (EUR million) }\end{array}$ & $\begin{array}{l}\text { Value added } \\
\text { (EUR million) }\end{array}$ & $\begin{array}{l}\text { Personnel } \\
\text { costs (EUR } \\
\text { million) }\end{array}$ \\
\hline Lithuania & 5,5 & 40,6 & 689,0 & 241,8 & 195,7 \\
\hline $\begin{array}{l}\text { Luxem- } \\
\text { bourg }\end{array}$ & 2,8 & 19,1 & $1.447,4$ & 676,5 & 541,2 \\
\hline Hungary & 29,3 & 127,6 & $3.148,4$ & 889,9 & 675,0 \\
\hline Malta & 2,2 & 17,5 & 820,7 & 319,3 & 182,4 \\
\hline $\begin{array}{l}\text { Nether- } \\
\text { lands }\end{array}$ & 54,0 & 408,7 & $20.861,7$ & $9.237,3$ & $5.403,1$ \\
\hline Austria & 47,5 & 291,0 & $17.157,0$ & $8.234,9$ & $5.604,2$ \\
\hline Poland & 49,0 & 238,3 & $7.094,7$ & $2.361,9$ & $1.318,1$ \\
\hline Portugal & 84,1 & 273,3 & $9.189,8$ & $3.413,5$ & $2.384,0$ \\
\hline Romania & 25,1 & 157,9 & $2.757,1$ & 923,2 & 555,3 \\
\hline Slovenia & 10,4 & 34,2 & $1.581,3$ & 582,3 & 405,8 \\
\hline Slovakia & 16,4 & 56,5 & $1.744,7$ & 406,5 & 307,6 \\
\hline Finland & 11,7 & 71,2 & $6.048,5$ & $2.108,3$ & $1.723,1$ \\
\hline Sweden & 31,4 & 189,3 & $14.356,7$ & $6.027,9$ & $4.814,3$ \\
\hline $\begin{array}{l}\text { United } \\
\text { Kingdom }\end{array}$ & 132,1 & $2.043,4$ & $101.962,9$ & $50.059,6$ & $28.155,6$ \\
\hline Norway & 11,3 & 97,6 & $8.520,8$ & $3.662,5$ & $3.107,4$ \\
\hline $\begin{array}{l}\text { Switzer- } \\
\text { land }\end{array}$ & 18,0 & 211,9 & $18.699,4$ & $9.970,9$ & $8.313,4$ \\
\hline & & & & \\
\hline
\end{tabular}

In absolute terms, the United Kingdom recorded the highest level of value added within the accommodation and food services industry in 2014 (EUR 50.1 billion), which was equivalent to $21.7 \%$ of the EU-28 total. France (15.7\%), Germany (15.6\%), Italy (11.9\%) and Spain (10.3\%) also contributed more than one tenth of EU-28 value added (Eurostat, 2017). These five member states collectively provided $75.5 \%$ of the EU-28's value added in the accommodation and food services industry in 2014. In employment terms, this unusually high concentration of activity within the largest EU member states was even more visible; as $70.9 \%$ of the accommodation and food services industry's workforce were employed in these five member states (shown in Figure 3). The United Kingdom had the largest share of EU-28 added value also for both accommodation and food services sub-industries; for accommodation services it contributed to EU-28 added value by $7.1 \%$, while for food and beverage services by $14.7 \%$ (Eurostat, 2017). 


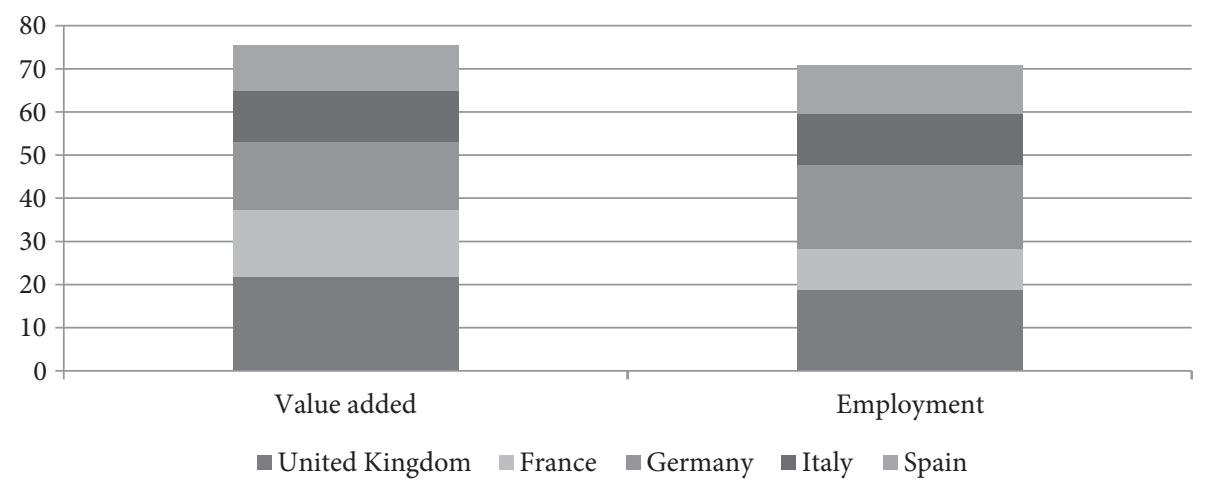

As a service industry, hotels and restaurants are keen on locations that are proximate to their potential markets because they seek increased demand from potential guests. As indicated by a model proposed by Yokeno (1968), hotels choose a central location. In this regard, there is a large demand for accommodation in the city center which may be the central business district or tourist district (Shoval, 2006; Shoval et al., 2011).

\section{Conclusion}

Tourism plays an important role in Europe and makes a considerable contribution to employment and regional development, as well as a range of other EU objectives, such as sustainable development or the enhancement of natural and cultural heritage. In addition, the European Union remains the world's number one tourist destination. The foodservice and accommodation industry is the largest part of tourism and makes a major contribution to the European economy.

Demand for hotels and restaurants is decided by external factors, such as the economic climate, customers' preferences, competitive pricing and industrial environment (Ruggero, 2010).

One of the main characteristics of tourism-related activities is their high income elasticity of demand, which increases or reduces more easily than for many other products or services. As such, spending on tourism generally decreases proportionally faster than consumers' income during times of economic slowdown. Moreover, political or economic uncertainties (for example, when exchange rates change rapidly) tend to lead to a diversion of tourism demand, resulting in shifts between outbound tourism and domestic tourism. Furthermore, a downturn in economic fortunes is also likely to result in reduced business activity; this in turn may be reflected in fewer business trips and nights spent in hotels, as well as less corporate entertainment.
AN ANALYSIS OF FOODSERVICE AND ACCOMMODATION

Edyta Gheribi

Alessandro Bonadonna

Figure 3.

Concentration of value added and employment in accommodation and food service activities in EU-28 in 2014 (cumulative share of the five principal member states as a $\%$ of the

Eu-28 total)

Source: Eurostat. 
AN ANALYSIS OF FOODSERVICE AND ACCOMMODATION

Edyta Gheribi

Alessandro Bonadonna
The industry is very responsive to economic conditions, supporting job creation and economic growth in the good times, but also vulnerable to revenue raising policy measures in a downturn. It is important that decision-makers recognize the major contribution made by the European hospitality industry to the EU economy and society and that its good health is essential for EU job creation and growth. The prosperity of other European business industries, including agriculture, tourism and brewing is also at stake here. This is why a policy framework that truly values the hospitality industry is needed. This study clearly demonstrates that, within a supportive legal and fiscal environment, the hospitality industry can be a key driver for job creation in Europe, even in times of crisis.

\section{Implications, limitations and future research}

On the one hand, this study shows that the foodservice and accommodation subindustries are useful to improve the EU job market and support the economic growth. On the other, the results provide a small contribution to help public entities and hospitality industry to define and implement new system rules. However, the data collected have some limitations determined by the methodology applied that is based only on the elaboration of secondary statistical data. Indeed, the findings of the study are the initial results of a lengthy research that, in the future steps, will implement the involvement of stakeholders of hospitality supply chain in a qualitative statistical analysis.

\section{References}

Atkins, P., Bowler, I. (2001), Food in society: Economy, culture and geography, Arnold, London.

Barjolle, D., Sylvander, B. (2000), Protected Designations of origin and protected geographical indications in Europe: Regulation or policy?, Report for European Commission, Brussels.

Belliveau, S. (2005), "Resisting global, buying local: Goldsmith revisited", The Great Lake Geographer, Vol. 12 No. 1, pp. 45-53.

Boella, M.J. (2000), Employee relations. Human resource management in the hospitality industry, Nelson Thornes Ltd., Cheltenham, UK.

Busquets, J. (2010), Accommodations and consumption diversification in the sector of tourist accommodations and restaurant industries, and its effects on labour relations, study commissioned by the International Labour Organization, April 2010.

Coroş, M.M., Negruşa, A.L. (2014), “Analysis of Romania’s and Transylvania’s tourist supply development and performance", Amfiteatru Economic Journal, Vol. 16 No. 8, pp. 1312-1326.

European Commission (2010), Communication from the commission to the European Parliament, the council, the European economic and social committee and the committee of the regions, Europe, the world's No 1 tourist destination - a new political 
framework for tourism in Europe, Brussels, available at: http://eur-lex.europa.eu/ legal-content/EN/TXT/?uri=CELEX:52010DC0352.

FERCO - European Federation of Contracting Catering Organisations (2015), European Industry Overview. Food Service Europe, available at: www.foodserviceeurope.org/ en/european-industry-overview (accessed 17 September 2015).

GDFHTS (2010), Developments and challenges in the hospitality and tourism sector, Issues paper for discussion at the Global Dialogue Forum for the Hotels, Catering, Tourism Sector, International Labour Organization, Geneva.

Gheribi, E. (2015a), "Factors affecting the development of catering enterprises in Poland", Ekonomiczne Problemy Turystyki, Vol. 3 No. 31, pp. 207-220. DOI: 10.18276/ ept.2015.3.31-11

Gheribi, E. (2015b), "Restaurant and Hotel Market in Poland", Service Management, Vol. 16, pp. 57-63. DOI: 10.18276/smt.2015.16-06

Gheribi, E. (2017), “The Foodservice Business in Big Polish Cities”, Urban Development Issues, Vol. 53 No. 1, pp. 57-63. DOI: 10.1515/udi-2017-0006

Gheribi, E., Ejsmont, A. (2018), "Effective Human Resources Management Practices as a Competitive Advantage Factor in Selected Examples from Foodservice Family Businesses", Przedsiębiorczość i Zarządzanie, Vol. 19, pp. 359-374.

Gheribi, E., Voytovych, N. (2018), "Impact of socio-economic changes for competitiveness in the foodservice industry", Acta Scientiarum Polonorum. Oeconomia, Vol. 17 No. 1, pp. 23-32.

Ikerd, J.E. (2011), "Local food: revolution and reality", Journal of agriculture \& food information, Vol. 12 No. 1, pp. 49-57.

International Labour Organization (2010), Developments and challenges in the hospitality and tourism sector. Global Dialogue Forum for the Hotels Catering, Tourism Sector, Geneva.

Koens, A., Wood, R.C. (2017), “An analysis of international employment levels in hospitality occupations using secondary statistics", International Journal of Tourism Research, Vol. 19 No. 5, pp. 496-504.

Morgan, K., Mardsen, T., Murdoch J. (2006), Worlds of Food: Place, Power, and Provenance in the Food Chain, Oxford Geographical and Environmental Studies, Oxford University Press, Oxford.

Peira, G., Soster, M., Bonadonna, A. (2018), 'The Italian public policies for the economy of taste: The regional point of view", Quality - Access to Success, Vol. 19 No. 164, pp. 137-144.

Peri, C. (2006), "The universe of food quality", Food Quality and Preference, Vol. 17 No. $1-2$, pp. 3-8.

Robinson, P., Lück, M., Smith, S. (2013), Tourism, Oxfordshire: CABI, Wallingford.

Ruggero, S. (2010), "Hotel performance: state of the art", International Journal of Contemporary Hospitality Management, Vol. 22 No. 7, pp. 920-952.

Sheresheva, M.Y., Oborin, M.S., Polyanskaya, E.E. (2018), "International hotel chains in Russia: The prospects and challenges of movement from megacities to smaller cities in Russian regions", Worldwide Hospitality and Tourism Themes, Vol. 10 No. 4, pp. 421-435. DOI: 10.1108/WHATT-04-2018-0023
AN ANALYSIS OF FOODSERVICE AND ACCOMMODATION

Edyta Gheribi Alessandro Bonadonna 
AN ANALYSIS OF FOODSERVICE AND ACCOMMODATION

Edyta Gheribi

Alessandro Bonadonna
Shoval, N. (2006), "The geography of hotels in cities: An empirical validation of a forgotten model", Tourism Geographies, Vol. 8 No. 1, pp. 56-75.

Shoval, N., McKercher, B., Birenboim, A. (2011), "Hotel location and tourist activity in cities", Annals of Tourism Research, Vol. 38 No. 4, pp. 1594-1612.

Slattery, P., Gamse, I., Roper, A. (2008), “The development of international hotel chains in Europe”, in: Olsen, M.D., Zhao, J.L. (Eds.), Handbook of Hospitality Strategic Management, Butterworth-Heinemann, London, pp. 41-67.

Sobaih, A.E.E. (2015), "Hospitality Employment Issues in Developing Countries: The Case of Egypt", Journal of Human Resources in Hospitality \& Tourism, Vol. 14 No. 3 , pp. 221-243. DOI: 10.1080/15332845.2014.904167

Tregear, A., Kuznesof, S., Moxey, A. (1998), "Policy initiatives for regional foods: some insights from consumer research", Food Policy, Vol. 23 No. 5, pp. 383-394.

Vanhonacker, F., Verbeke, W., Guerrero, L. Claret, A., Contel, M., Scalvedi, L., Zawkoska-Biemans, K., Gutkowska, K., Sulmont-Rossé, C., Raude, J., Granli, B., Hersleth, M. (2010), "How European Consumer define the concept of Traditional food: evidence from survey in six countries", Agribusiness, Vol. 26 No. 4, pp. 453-476.

World Travel and Tourism Center (WTTC) (2017), Travel and Tourism Economic Impact 2017, available at: https://www.wttc.org/-/media/files/reports/economic-impactresearch/regions-2017/world2017.pdf.

Yokeno, N. (1968), "Application of the Thunen-Weber analysis to the tourist industry location”, Sophia Economic Review, Vol. 15 No. 3, pp. 89-94. 